Theoretical

and Applied

Climatology

(C) Springer-Verlag 1998

Printed in Austria

Department of Biology and Center for Great Lakes and Aquatic Sciences, Natural Science Building, University of Michigan, Ann Arbor, USA

\title{
Role of Climate in the Modern Condition of Lake Victoria
}

\section{J. T. Lehman}

With 1 Figure

Received April 20, 1997

Revised January 1, 1998

\begin{abstract}
Summary
Comparison of historical and recent climatic data for Lake Victoria, a great lake in the high elevation tropics of East Africa, demonstrates changes in surface temperature, air moisture, atmospheric transparency, and wind shear from conditions 35 years ago. The changes appear to be part of a global change in climate conditions of the high elevation tropics. The physical and ecological conditions of Lake Victoria appear responsive to lake-atmosphere interactions through mechanisms of wind stress and surface heat fluxes. Lake temperatures, mixing regimes, oxygen levels, and primary production have changed in parallel to air temperature, humidity, atmospheric transparency, and wind speeds between about 1960 and the present. Data indicate strong coupling between meteorological components of lake heat balance and both biological and chemical conditions. Many features of the apparent modern eutrophication of Lake Victoria may have been accelerated or exaggerated by the climate effects. The analysis suggests a mechanism for feedback of climate on lake condition which, if general, might provide a modern analog for periodic changes reported in the fossil diatom community of the lake over the past 10 millenia.
\end{abstract}

\section{Introduction}

The modern condition of Lake Victoria has attracted scientific attention for several reasons. The basin encloses one of the largest freshwater lakes on the planet, and is an important hydrologic feature of East Africa. Its regional importance lies in the high potential yields of its fisheries as a source of inexpensive animal protein. Lake Victoria was studied intensely during the late 1950s and early 1960s, and baseline conditions at that time were established for food web components, biological productivity, hydrology, and limnological properties including temperature and dissolved nutrients (Talling, 1965, 1966). Subsequently, the condition of the lake has changed quantitatively.

The numerous changes in lake condition from 35 years ago have been summarized by several authors (Hecky, 1993; Muggide, 1993; Lehman and Branstrator, 1994; Hecky et al., 1994; Bugenyi and Magumba, 1996; Lehman, 1996). Lake Victoria presently exhibits increased algal biomass and increased concentrations of particulate chlorophyll. The species composition of the planktonic algae has changed, as well: there are proportionally more cyanobacteria and fewer large diatoms and chlorophyte algae. In particular, the heavily silicified diatom Aulacoseira (formerly called Melosira) is now absent from the flora, and concentrations of dissolved silicate in surface lake waters have declined. Whereas rates of primary production have accelerated near the lake surface, rates of decomposition have depressed dissolved oxygen concentrations over as much as the deepest one-third of the water column (Hecky et al., 1994). The lake is approximately $0.5^{\circ} \mathrm{C}$ warmer than in 1960 (Bugenyi and Magumba, 1996; Ochumba, 1996), and it exhib- 
its reduced water transparency, stronger stability of thermal stratification, and decreased photic zone depth. Concentrations of phosphorus have increased in offshore waters, and concentrations of sulfate have been reduced. The species richness of its endemic fish fauna has declined, and the abundance of an introduced predatory fish, Nile perch, has increased to dominate the fishery.

Other hypothesized changes may elude definitive comparison because there are limited historical data. These potential differences include increased rates of $\mathrm{N}$-fixation and denitrification (Hecky, 1993), increased N-limitation of algae not capable of $\mathrm{N}$-fixation (Lehman and Branstrator, 1994), and increased light limitation of phytoplankton (Mugidde, 1993).

Three hypotheses had been proposed to explain the observed changes in the condition of the lake, particularly its altered phytoplankton composition, increased biomass, and decreased hypolimnetic oxygen:

H1: Eutrophication resulting from land clearing, growth of human and cattle populations, and increased nutrient income to the lake, particularly as phosphate, has caused Lake Victoria to resemble temperate zone lakes similarly subjected to increased $\mathrm{P}$ loading. In particular, these effects include the loss of large diatoms, increases in bluegreens, and expanded deficits of hypolimnetic oxygen.

$\mathrm{H} 2$ : Trophic alterations caused by a cascade of predator-prey interactions triggered by the introduction of Nile perch has eliminated endemic herbivores and permitted the algae to grow unrestrained.

H3: Climate variations have caused reduced lake mixing, elevated temperatures, altered water balance, and a suite of chemical and biological consequences of altered mixing state.

Hypothesis 2 has been largely discounted because stratigraphic evidence in recent sediments indicates that biotic changes in the flora preceded the introduction of the Nile perch (Lipiatou et al., 1996). Thus, under the general principle that effect can not precede cause, the predator could not cause the major lake system changes. On the other hand, there is little doubt that the introduced piscivore decimated the endemic fish fauna of the lake. Hypothesis 1 had seemed most plausible and sufficient as an explanation, because the modern changes were believed to be unique (Hecky, 1993). Recently, however, detailed fossil stratigraphy of diatoms during the last 10,000 years has indicated that the modern events are not unique (Stager et al., 1997). Instead, the dominance of heavily silicified diatoms, proxy indicators of deep and sustained lake mixing conditions, seem to have waned repeatedly and episodically over time periods of centuries or less. This paleolimnological indication of alternating cycles of strong mixing and comparative stability raises the potential of climate variations.

Hypothesis 3 is not a rigid alternative to the eutrophication hypothesis, because climate variations can intensify and accelerate the effects of nutrient income. Climate variation is linked to lake condition through mechanisms of heat budget and mixing regime of the lake, which are the consequences of atmosphere-lake interaction. Biological and chemical changes in Lake Victoria are consistent with diminished vertical mixing and thus with increased physical stability of stratification (Hecky, 1993; Lehman, 1996). Mixing depths are influenced by heat and momentum transfers at the lake surface. Shallow mixing permits higher algal biomass to develop in nutrient rich surface waters, promotes the loss of heavy diatoms, and reduces the ventilation of deeper waters with oxygen.

Diaz and Graham (1996) recently pointed out that above average SST in the tropical Pacific from the late 1950s to 1990 seemed to cause increased surface air temperatures at tropical sites $>1000 \mathrm{~m}$ in elevation. Similar changes were identified for humidity and freezing heights in the tropical atmosphere. With its surface elevation at more than $1100 \mathrm{~m}$, Lake Victoria is within the zone susceptible to this identified climate change. Evidence that climate change may be behind some of the recent changes is given by striking changes to the lake's water balance in terms of both precipitation and evaporation (Ba and Nicholson, 1997; Xin and Nicholson, 1998), resulting in elevated stage height of the lake compared to historical levels (Bugenyi and Magumba, 1996).

Changes in heat content and seasonal mixing depth of lakes and surface ocean waters are well 
understood consequences of heat and momentum fluxes (Price, 1981; Monismith, 1985; Spigel et al., 1986; Imberger and Patterson, 1990). For Lake Victoria, surface water temperatures exceed mean daily air temperatures all year round (Newell, 1960; Ochumba, 1996). Thus heat gained from irradiance is perennially lost to the atmosphere at rates that maintain surface water temperatures near or above $25^{\circ} \mathrm{C}$. The heat loss mechanisms are by long wave radiation, conduction, and evaporation; outflow effects are negligible (Talling, 1966; Newell, 1960).

Net heat loss by long wave radiation depends on the absolute temperature difference (K) between surface water and the sky (Keijman, 1974). Variation in the aerosol or particulate content of the atmosphere can change the net gray body long wavelength radiative heat flux from the lake surface. In particular, decreased atmospheric visibility can reduce this heat loss, depending on the specific absorption characteristics of the aerosols, water vapor, or particulates in the air.

Heat loss by conduction is commonly formulated as a linear function of wind speed and the temperature gradient from lake surface to air (Strub and Powell, 1987). For Lake Victoria, with its mean surface temperature warmer than the mean air temperature, either decreased wind speed or elevated air temperatures can decrease this flux. Latent heat loss by evaporation is interlinked with conduction loss and is typically also formulated as a linear function of wind speed and humidity differences in the air compared with a water saturated atmosphere at equilibrium with the lake surface temperature. Either decreased wind speed or increased relative humidity in the bulk atmosphere will decrease this heat flux. The heat balance of surface waters is fundamentally self-correcting; a temporary decrease in heat loss will be compensated by elevated water temperature, with resultingly increased heat flux by all three heat loss mechanisms.

Elevated temperature observed for Lake Victoria could hypothetically result from increased air temperature, increased air moisture, decreased wind speeds, or decreased atmospheric transparency to long wave radiation. Changes in the wind speed, in particular, could further promote changes in biomass and deoxygenation through mechanisms linked to mixed layer dynamics. Mixed layer depth is proportional to the square of mean horizontal velocities in the mixed layer (Imberger and Patterson, 1990; Eq. 4.24). These mixed layer mean velocities, in turn, are strongly influenced by surface wind stress. Velocity shear is also a main determinant of the rate of entrainment of water at the thermocline (Price, 1981; Imberger and Patterson, 1990) and hence of vertical exchange rates and ventilation of deep water. Thus, if wind speeds decrease, the mixed layer will shoal and entrainment rates of deeper water will slacken.

Shallow mixed layers can support higher concentrations of algae than can deep mixed layers, owing to limitation effects by self-shading at deeper mixed depths (Straskraba, 1980). The basic reason for this inverse relationship between potential biomass and mixing depth is that photosynthetically active light is attenuated by algal particles. At high biomass levels, the compensation point for photosynthesis and respiration is reached at shallow depths. Thus, high concentrations of algae are consistent only with shallow mixing depths; deep mixing causes the extended periods spent by algae below the compensation point to induce light limitation and thereby force a decline in biomass levels through excess respiration over photosynthesis.

\section{Methods}

I investigated the case for climate control of lake conditions by comparing mean monthly meteorological observations from time periods for which coherent data exist. I used National Climate Data Center station 637050 at Entebbe, Uganda, on the northwest shore of Lake Victoria, station 637080 at Kisumu, Kenya on the lake's eastern margin, and station 637560 at Mwanza, Tanzania at the southern shore of the lake (Fig. 1). Earlier studies have demonstrated that weather conditions vary systematically from south to north across the lake (Newell, 1960), but that the same temporal and seasonal trends occur across the entire basin. Properties investigated were surface air temperature, dew point temperature, station-level barometric pressure, visibility, average wind speed, and maximum wind speed. Relative humidity was calculated from temperature and dew point. 


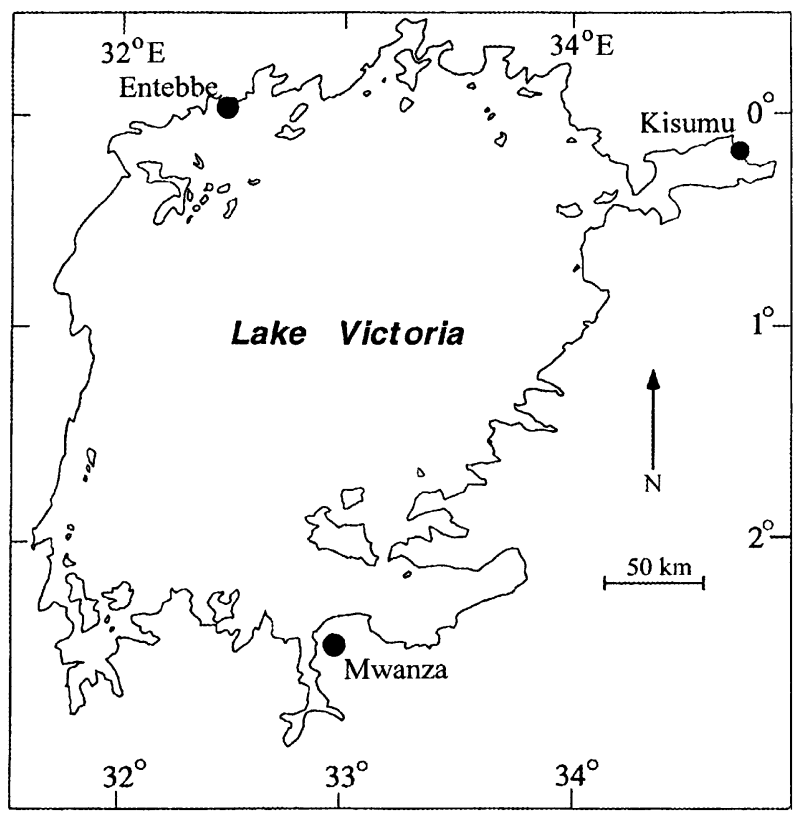

Fig. 1. Locations of the three climate data stations around Lake Victoria: Entebbe, Uganda (station 637050), Kisumu, Kenya (station 637080), and Mwanza, Tanzania (station 637560). Map is courtesy of T. C. Johnson

The source of data was the National Climate Data Center of the U.S. National Oceanic and Atmospheric Administration. For 1959 to 1961 and 1993, station Summary of Day (SOD) records were obtained from NCDC archives. For 1994 to 1996, SOD records were extracted from the NCDC Global summary of day records that were accessible in electronic form (www.ncdc.noaa.gov).

The 36 months from Jan 1959 to Dec 1961 were defined as the reference period. The reference period corresponds to an interval for which there are both meteorological data and historical limnological data about lake condition. These historical data represent a baseline for the lake and its climatic environment before modern changes became evident. Reference values for each property by month were computed as the mean value for each month across the 3 years. Month-specific anomalies were then computed for each property by subtracting the reference means from each monthly value individually. Monthly data were excluded if there were fewer than 6 observation days within a single month from which to construct means and extreme observations.
Analysis of anomalies was by two methods. First, anomalies were subjected to a two sample t-test (modern versus reference periods), under a priori assumptions (one-tail test) that deviations should be in the expected direction from zero. The a priori tests were for deviations that could contribute to observed changes in the lake: increased air temperature, increased dew point, increased relative humidity, decreased atmospheric pressure, decreased visibility, and decreased wind speed. Second, the total numbers of positive and negative anomalies were tabulated and compared to a null hypothesis of $1: 1$ ratio.

Changes in atmospheric transparency were analyzed further by sorting reported mean daily visibility into two categories: reduced visibility (mean visibility less than $20 \mathrm{~km}$ ) or unrestricted visibility (visibility greater than or equal to $20 \mathrm{~km}$ ). The recorded frequencies (i.e., numbers of days) for each category were then compared between the reference and test periods.

\section{Results and Discussion}

There is evidence for deviations in all climate data categories at one or more stations (Table 1). The deviations are almost universally in the direction that could contribute to elevated lake water temperature and reduced vertical mixing. By numerical trend, 17 of the 19 comparisons are in the predicted direction. Thirteen of the 19 contrasts exhibit deviations that are statistically significant in the predicted direction with less than $5 \%$ probability of error, which is obviously far better than would be expected by chance. The single notable exception seems to be mean wind speed at Kisumu, Kenya, which has increased by about $1 \mathrm{~m} \mathrm{~s}^{-1}$ on average over the 35 years period. In all other respects, increased atmospheric humidity and decreased wind speeds probably contribute to the favorable water balance for the lake which cause its level to remain about $1 \mathrm{~m}$ higher than the base level that was maintained before the intense rains at the end of 1961, during 1963, and again in the late 1970s (Bugenyi and Magumba, 1996).

The pattern of daily variation in wind speed has changed somewhat, as well. The ratio of daily maximum sustained wind speed to mean daily wind speed, a ratio which has a lognormal 
Table 1. Climate Data Anomalies for Month Mean Measurements from April 1993 to December 1996, with Reference to Mean Conditions by Month from January 1959 to December 1961 (36 Month Reference Period)

Entebbe, Uganda (Station 637050): April 1993 to December 1996

\begin{tabular}{lcccccc}
\hline Property & $\begin{array}{l}\text { Mean } \\
\text { anomaly }\end{array}$ & SE & $\mathrm{t}$ & $\begin{array}{l}\text { Positive } \\
\text { anomalies }\end{array}$ & $\begin{array}{l}\text { Negative } \\
\text { anomalies }\end{array}$ & $\begin{array}{l}\chi^{2} \\
\text { probability }\end{array}$ \\
\hline $\begin{array}{l}\text { Temperature } \\
\left({ }^{\circ} \mathrm{C}\right)\end{array}$ & 0.509 & 0.079 & 6.42 & 35 & 6 & $<0.00001$ \\
$\begin{array}{l}\text { Dew point } \\
\left({ }^{\circ} \mathrm{C}\right)\end{array}$ & 0.689 & 0.042 & 16.59 & 41 & 0 & $<0.00001$ \\
$\begin{array}{l}\text { Relative } \\
\text { humidity }(\%)\end{array}$ & 0.990 & 0.425 & 2.33 & 26 & 15 & 0.086 \\
$\begin{array}{l}\text { pressure } \\
(\mathrm{hPa})\end{array}$ & -0.59 & 0.09 & -6.37 & 7 & 33 & $<0.0001$ \\
$\begin{array}{l}\text { Visibility } \\
(\mathrm{km})\end{array}$ & -20.48 & 0.48 & -42.44 & 0 & 41 & $<0.00001$ \\
$\begin{array}{l}\text { Wind speed } \\
\left(\mathrm{m} \mathrm{s}^{-1}\right)\end{array}$ & -0.130 & 0.058 & -2.23 & 17 & 24 & 0.27 \\
$\begin{array}{l}\text { Maximum } \\
\text { wind speed }\left(\mathrm{m} \mathrm{s}^{-1}\right)\end{array}$ & -1.54 & 0.59 & -2.59 & 10 & 31 & 0.001 \\
\hline
\end{tabular}

Kisumu, Kenya (Station 637080): January 1994 to December 1996

\begin{tabular}{lcccccc}
\hline Property & $\begin{array}{l}\text { Mean } \\
\text { anomaly }\end{array}$ & SE & $\mathrm{t}$ & $\begin{array}{l}\text { Positive } \\
\text { anomalies }\end{array}$ & $\begin{array}{l}\text { Negative } \\
\text { anomalies }\end{array}$ & $\begin{array}{l}\chi^{2} \\
\text { probability }\end{array}$ \\
\hline $\begin{array}{l}\text { Temperature } \\
\left({ }^{\circ} \mathrm{C}\right)\end{array}$ & 0.246 & 0.097 & 2.52 & 24 & 12 & 0.046 \\
$\begin{array}{l}\text { Dew point } \\
\left({ }^{\circ} \mathrm{C}\right)\end{array}$ & 0.591 & 0.105 & 5.64 & 30 & 6 & $<0.0001$ \\
$\begin{array}{l}\text { Relative } \\
\text { humidity }(\%)\end{array}$ & 1.31 & 0.75 & 1.75 & 20 & 16 & 0.50 \\
$\begin{array}{l}\text { Visibility } \\
(\mathrm{km})\end{array}$ & -14.89 & 0.49 & -30.52 & 0 & 36 & $<0.00001$ \\
$\begin{array}{l}\text { Wind speed } \\
\left(\mathrm{m} \mathrm{s}^{-1}\right)\end{array}$ & 0.84 & 0.06 & 14.23 & 36 & 0 & $<0.00001$ \\
$\begin{array}{l}\text { Maximum } \\
\text { wind speed }\left(\mathrm{m} \mathrm{s}^{-1}\right)\end{array}$ & 0.76 & 0.56 & 1.36 & 21 & 15 & 0.32 \\
\hline
\end{tabular}

Mwanza, Tanzania (Station 637560): January 1994 to December 1996

\begin{tabular}{lcccccc}
\hline Property & $\begin{array}{l}\text { Mean } \\
\text { anomaly }\end{array}$ & SE & $\mathrm{t}$ & $\begin{array}{l}\text { Positive } \\
\text { anomalies }\end{array}$ & $\begin{array}{l}\text { Negative } \\
\text { anomalies }\end{array}$ & $\begin{array}{l}\chi^{2} \\
\text { probability }\end{array}$ \\
\hline $\begin{array}{l}\text { Temperature } \\
\left({ }^{\circ} \mathrm{C}\right)\end{array}$ & 0.328 & 0.195 & 1.68 & 13 & 11 & 0.68 \\
$\begin{array}{l}\text { Dew point } \\
\left({ }^{\circ} \mathrm{C}\right)\end{array}$ & 0.325 & 0.174 & 1.86 & 18 & 6 & 0.014 \\
$\begin{array}{l}\text { Relative } \\
\text { humidity }(\%)\end{array}$ & 0.09 & 1.12 & 0.08 & 14 & 10 & 0.41 \\
$\begin{array}{l}\text { Visibility } \\
(\mathrm{km})\end{array}$ & -18.72 & 0.48 & -38.60 & 0 & 24 & $<0.00001$ \\
$\begin{array}{l}\text { Wind speed } \\
\left(\mathrm{m} \mathrm{s}^{-1}\right)\end{array}$ & -0.90 & 0.14 & -6.32 & 3 & 21 & $<.001$ \\
$\begin{array}{l}\text { Maximum } \\
\text { wind speed }\left(\mathrm{m} \mathrm{s}^{-1}\right)\end{array}$ & 1.74 & 1.37 & 1.27 & 9 & 15 & 0.22 \\
\hline
\end{tabular}


Table 2. Independent Samples t-Tests on Ratios (Natural Logarithm Transformation) of Maximum Daily Wind Speed to Mean Daily Wind Speed at 3 Climate Stations for Lake Victoria. Contrasts are between Reference Historic and Modern Periods, as Defined in Table 1

\begin{tabular}{llllllrrc}
\hline \multicolumn{7}{c}{ Reference Historic } & \multicolumn{7}{c}{ Modern } \\
\hline Station & Mean & SE & N & Mean & SE & N & t & Probability \\
\hline Entebbe & 0.890 & 0.230 & 1096 & 0.552 & 0.244 & 982 & 32.4 & $<0.0001$ \\
Kisumu & 1.283 & 0.284 & 1096 & 0.974 & 0.264 & 1077 & 26.3 & $<0.0001$ \\
Mwanza & 0.488 & 0.175 & 1095 & 0.537 & 0.339 & 349 & -2.6 & 0.009 \\
\hline
\end{tabular}

frequency distribution, has declined at the two northern stations, but not at Mwanza (Table 2). Thus, the intensity of elevated wind shear events has decreased over much of the basin. The limnological significance of variations in wind speed lies in the observation that wind stress varies with the square of the wind velocity (Imberger and Patterson, 1990), and because the drag coefficient increases with velocity (Hsu, 1986; Stewart, 1974) owing to increased surface roughness with increased wave heights. Surface wind drift currents are therefore generated by this strongly nonlinear relationship between wind speed and surface wind stress.

The temperature increases observed over land might magnify the nocturnal land breeze, and change the circulation system over the lake $(\mathrm{S}$. Nicholson, personal communication). Consequently, it might be informative for future investigations to assemble daily minimum and maximum temperatures for parallel analyses.

One striking and universal feature of this analysis is the remarkable decline in atmospheric visibility between 1959-1961 and 1993-1996. The potential significance of this change to radiative heat balance at the lake surface is worthy of further investigation. At the present state of understanding, there is unfortunately insufficient information to link the conspicuous changes to total heat fluxes by an explicit mathematical formula. The explicit linkages are complicated by incomplete understanding of the spectral absorbance characteristics of the aerosols that are reducing modern atmospheric transparency, and by recent discovery that there are different diurnal patterns of cloudiness and rainfall over the lake compared with shore-based observing stations (Ba and Nicholson, 1997). Furthermore, visibility observations are notor- iously imprecise and subject to reporting bias ( $\mathrm{S}$. Nicholson, personal communication). There are no indications that reporting methods changed over the years, but because measurements are subjective, observer bias remains a potential factor. Table 3 illustrates that there has been an unmistakable shift in the number of days per year of unrestricted atmospheric visibility at all three recording stations around the lake, but that the effects are most pronounced at Entebbe in the north, and least pronounced at Mwanza in the south.

Diaz and Graham (1996) noted reduced ice cover in the tropical Andes, which parallel similar reductions in African tropical highlands (Hastenrath and Kruss, 1992). They proposed that a proximate mechanism for the changes exists in increased tropical SST. The authors also observed that the changes in temperature at high elevation should be linked to increased moisture contents in the lower troposphere. They hypothesized that the combination of increased temperatures and humidity was likely to have an impact on hydrological and ecological balances of high altitude ecosystems in the tropics. Virtually every recent change in Lake Victoria from limnological conditions recorded by Talling (1966) can be ascribed by cause and effect to consequences of altered mixing state (Lehman, 1996). It appears that Lake Victoria presents an example of ecosystem response to these climatic forcing functions.

The existence of strong climate variation does not preclude the effects of nutrient enrichment that are also believed to have contributed to the modern condition of Lake Victoria. Changes in land use and deforestation can have their effects amplified by the climate effects. Elevated lake levels have inundated terrestrial soils, with 
Table 3. Comparison of Atmospheric Visibility by Month, 1959-1961 Versus 1994-1996, as Number of Days (N) with Recorded Data for which Reported Mean Visibility was $<20 \mathrm{~km}$ or $\geq 20 \mathrm{~km} . \chi^{2}$ Statistical Tests were Performed with One Degree of Freedom

\begin{tabular}{|c|c|c|c|c|c|c|c|}
\hline \multirow[t]{2}{*}{ Station } & \multirow[b]{2}{*}{ Month } & \multicolumn{2}{|c|}{1959 to 1961} & \multicolumn{2}{|c|}{1994 to 1996} & \multirow[t]{2}{*}{$\chi^{2}$} & \multirow[t]{2}{*}{$P(d f=1)$} \\
\hline & & $\mathrm{N}(<20 \mathrm{~km})$ & $\mathrm{N}(\geq 20 \mathrm{~km})$ & $\mathrm{N}(<20 \mathrm{~km})$ & $\mathrm{N}(\geq 20 \mathrm{~km})$ & & \\
\hline \multirow[t]{12}{*}{ Entebbe } & Jan & 24 & 69 & 57 & 4 & 67.59 & $<0.0001$ \\
\hline & Feb & 12 & 73 & 45 & 2 & 82.19 & $<0.0001$ \\
\hline & Mar & 0 & 93 & 68 & 13 & 128.16 & $<0.0001$ \\
\hline & Apr & 0 & 90 & 50 & 19 & 95.13 & $<0.0001$ \\
\hline & May & 0 & 93 & 37 & 3 & 119.18 & $<0.0001$ \\
\hline & June & 7 & 83 & 60 & 2 & 117.96 & $<0.0001$ \\
\hline & July & 8 & 85 & 69 & 1 & 129.71 & $<0.0001$ \\
\hline & Aug & 1 & 92 & 81 & 2 & 164.18 & $<0.0001$ \\
\hline & Sept & 0 & 90 & 72 & 7 & 142.91 & $<0.0001$ \\
\hline & Oct & 0 & 93 & 84 & 4 & 165.65 & $<0.0001$ \\
\hline & Nov & 0 & 90 & 71 & 12 & 130.58 & $<0.0001$ \\
\hline & Dec & 3 & 90 & 74 & 3 & 146.65 & $<0.0001$ \\
\hline \multirow[t]{12}{*}{ Kisumu } & Jan & 1 & 92 & 43 & 50 & 52.51 & $<0.0001$ \\
\hline & Feb & 0 & 85 & 49 & 36 & 68.84 & $<0.0001$ \\
\hline & Mar & 0 & 93 & 31 & 61 & 37.65 & $<0.0001$ \\
\hline & Apr & 1 & 89 & 46 & 42 & 59.93 & $<0.0001$ \\
\hline & May & 0 & 93 & 34 & 59 & 41.61 & $<0.0001$ \\
\hline & June & 2 & 88 & 74 & 16 & 118.06 & $<0.0001$ \\
\hline & July & 11 & 82 & 67 & 26 & 69.24 & $<0.0001$ \\
\hline & Aug & 0 & 93 & 52 & 21 & 96.46 & $<0.0001$ \\
\hline & Sept & 0 & 90 & 45 & 45 & 60.00 & $<0.0001$ \\
\hline & Oct & 0 & 93 & 50 & 43 & 68.38 & $<0.0001$ \\
\hline & Nov & 0 & 90 & 33 & 57 & 40.41 & $<0.0001$ \\
\hline & Dec & 0 & 93 & 67 & 22 & 110.80 & $<0.0001$ \\
\hline \multirow[t]{12}{*}{ Mwanza } & Jan & 2 & 91 & 0 & 13 & 0.28 & 0.59 \\
\hline & Feb & 0 & 85 & 1 & 12 & 6.61 & 0.010 \\
\hline & Mar & 1 & 92 & 2 & 9 & 10.28 & 0.0013 \\
\hline & Apr & 1 & 89 & 5 & 16 & 17.16 & $<0.0001$ \\
\hline & May & 0 & 93 & 4 & 18 & 17.52 & $<0.0001$ \\
\hline & June & 0 & 90 & 4 & 43 & 7.89 & 0.005 \\
\hline & July & 0 & 93 & 11 & 42 & 20.87 & $<0.0001$ \\
\hline & Aug & 0 & 93 & 7 & 47 & 12.66 & 0.0004 \\
\hline & Sept & 0 & 90 & 4 & 45 & 7.56 & 0.006 \\
\hline & Oct & 0 & 93 & 8 & 23 & 25.66 & $<0.0001$ \\
\hline & Nov & 5 & 85 & 6 & 23 & 5.99 & 0.014 \\
\hline & Dec & 0 & 93 & 7 & 9 & 43.48 & $<0.0001$ \\
\hline
\end{tabular}

possible consequences to nutrient income of $\mathrm{P}$, in a region characterized by easily weathered carbonatites that are rich in apatite phosphates (Reedman, 1984). It may be most accurate to regard the climate change hypothesis and the eutrophication hypothesis not as dichotomous alternatives, but as hierarchical elements of a single explanatory theory.

The evidence supports an interpretation as follows. Modern climate conditions have con- tributed to a lake that is warmer and which mixes less deeply and less thoroughly than it did earlier in the century. Wind stress and surface cooling by radiative and evaporation losses, which are sources for the total kinetic energy of the mixed layer (Spigel et al., 1986), have declined. Favorable water balance and elevated humidity have contributed to the flooding of previously riparian and terrestrial soils. The submerged soils, as well as the runoff from deforested land, are rich in 
phosphates because of the indigenous mineral content of easily erodable basic volcanic rocks. Weathering rates may have been accelerated further by strong acids now present in global precipitation. The net result is a phosphate rich water column with a shallow mixed layer and weakened rates of both vertical and horizontal mixing.

Given adequate nutrients, the shallow mixed layer supports elevated algal biomass. The increased quantities of surface algae in turn suppress dissolved nutrients. Because phosphate is present at great stoichiometric excess in proportion to mean protoplasmic composition, both nitrate and silicate are depleted differentially with respect to $\mathrm{P}$ in surface water. $\mathrm{N}$ fixation by diazotrophic cyanobacteria cannot restore stoichiometric equilibrium for $\mathrm{N}$ because the source of new organic $\mathrm{N}$ is counterbalanced by denitrification, and denitrification operates as an efficient sink for $\mathrm{N}$ in anoxic deep water. Consequently, the algae remain strongly $\mathrm{N}$ limited. Lower rates of vertical mixing restrain the resupply of $\mathrm{Si}$ to the surface layer. The modern diatoms are small, weakly silicified Nitzschia species, which maintain their buoyancy in the weakly mixed surface layer by commensal association with colonial cyanobacteria, Microcystis. The deep waters remain hypoxic or anoxic for much of the year because at warm water temperatures the richly organic sediments consume oxygen faster than it is mixed downward.

One corollary to this explanation is that the modern state of Lake Victoria is at least partially reversible if climate conditions revert to their pre-1960s levels. Deeper mixing depths could be predicted to suppress algal concentrations offshore through light limitation. More vigorous vertical mixing would promote the success of heavily silicified diatoms which export the products of their primary production from mixed layer to sediments more rapidly than do cyanobacteria or small diatoms. Increased ventilation of deep water resulting from mixing would replenish oxygen and restore some of the deep water fish habitat that has been lost.

An analogy to the predicted effects of deeper and stronger mixing can be seen in the case of Lake Albert (Talling, 1963), which has modern phosphate concentrations even higher than those of Lake Victoria, but which maintains a low algal biomass in its offshore region because of strong wind stress and sustained deep mixing (Lehman et al., 1998).

Although the data reported here permit tests with high levels of statistical significance, the analysis is based on a contrast of two 3-year periods separated by 35 years. For greatest reliability about the generality of these conclusions, longer time series from additional climate stations should now be inspected.

Finally, the apparent sensitivity of Lake Victoria to climate variations does not mean that nutrient income and its effects should be discounted. Phosphate concentrations in the offshore region of Victoria are higher now than reported by Talling (1965), and it is $\mathrm{P}$ that appears to set a limit on the total lakewide potential biomass production (Hecky, 1993). Mixed layer dynamics are applicable only to the offshore regions of the lake. Lehman and Branstrator (1994) have pointed out that essentially all inorganic $\mathrm{P}$ is converted to organic form in the nearshore before the water exits the lake at the Source of the Nile. Thus, management efforts to reduce $\mathrm{P}$ income to the lake can be predicted to be rewarded with lower algal biomass levels in nearshore regions, regardless of the climate change scenario.

\section{Acknowledgements}

The author thanks Sharon Nicholson for providing helpful comments about the text. This work was supported in part by a grant from the U. S. National Science Foundation.

\section{References}

Ba, M. B., Nicholson, S. E., 1997: Analysis of convective activity and its relationship to the rainfall over the Rift Valley lakes of East Africa during 1983-1990 using the METEOSAT infrared channel. J. Climate Appl. Meteorol. (in press).

Bugenyi, F. W. B., Magumba, K. M., 1996: The present physicochemical ecology of Lake Victoria, Uganda. In: Johnson, T. C., Odata, E. (eds.) The Limnology, Climatology, and Paleoclimatology of the East African Lakes. Amsterdam: Gordon and Breach, pp. 141-154.

Diaz, H. F., Graham, N. E., 1996: Recent changes in tropical freezing heights and the role of sea surface temperature. Nature, 383, 152-155.

Hastenrath, S., Kruss, P. D., 1992: Greenhouse indicators in Kenya. Nature, 355, 503.

Hecky, R. E., 1993: The eutrophication of Lake Victoria. Verh. Internat. Verein. Limnol., 25, 39-48. 
Hecky, R. E., Bugenyi, F. W. B, Ochumba, P., Gophen, M., Muggide, R., Kaufman, L., 1994: Deoxygenation of the deep water of Lake Victoria. Limnol. Oceanogr., 39, 1476-1480.

Hsu, S. A., 1986: A mechanism for the increase of wind stress (drag) coefficient with wind speed over water surfaces: a parametric model. J. Physical Oceanogr., 16, 144-150.

Imberger, J., Patterson, J. C., 1990: Physical Limnology. In: Hutchinson, J. W., Wu, T. Y. (eds.), Advances in Applied Mechanics, vol. 27, 303-475.

Keijman, J. Q., 1974: The estimation of the energy balance of a lake from simple weather data. Bound.-Layer Meteor., 7, 399-407.

Lehman, J. T., Branstrator, D. K., 1993: Effects of nutrients and grazing on the phytoplankton of Lake Victoria. Verh. Internat. Verein. Limnol., 25, 850-855.

Lehman, J. T., Branstrator, D. K., 1994: Nutrient dynamics and turnover rates of phosphate and sulfate in Lake Victoria, East Africa. Limnol. Oceanogr., 39, 227233.

Lehman, J. T., 1996: Pelagic food webs of the East African Great Lakes. In: Johnson, T. C., Odata, E., (eds.) The Limnology, Climatology and Paleoclimatology of the East African Lakes. Amsterdam: Gordon and Breach, pp. 281301.

Lehman, J. T., Litt, A. H., Mugidde, R., Lehman, D. A., 1998: Nutrients and plankton biomass in the rift lake sources of the White Nile: Lakes Albert and Edward. In: Lehman, J. T. (ed.) Environmental Change and Response in East African Lakes. Amsterdam: Kluwer, pp. 157-172.

Lipiatou, E., Hecky, R. E., Eisenreich, S. J., Lockhart, L., Muir, D., Wilkinson, P., 1996: Recent ecosystem changes in Lake Victoria reflected in sedimentary natural and anthropogenic organic compounds, In: Johnson, T. C., Odata, E. (eds.) The Limnology, Climatology and Paleoclimatology of the East African Lakes. Amsterdam: Gordon and Breach, pp. 523-541.

Monismith, S. G., 1985: Wind-forced motions in stratified lakes and their effect on mixed-layer shear. Limnol. Oceanogr., 30, 771-783.

Mugidde, R., 1993: The increase in phytoplankton primary productivity and biomass in Lake Victoria (Uganda). Verh. Internat. Verein. Limnol., 25, 846-849.
Newell, B. S., 1960: The hydrology of Lake Victoria. Hydrobiologia, 15, 363-383.

Ochumba, P. B. O., 1996: Measurement of water currents, temperature, dissolved oxygen and winds on the Kenyan Lake Victoria. In: Johnson, T. C., Odata, E. (eds.) The Limnology, Climatology and Paleoclimatology of the East African Lakes. Amsterdam: Gordon and Breach, pp. $155-167$.

Price, J. F., 1981: Upper ocean response to a hurricane. J. Physical Oceanogr., 11, 153-175.

Reedman, J. H., 1984: Resources of phosphate, niobium, iron, and other elements in residual soils over the Sukulu Carbonatite Complex, Southeastern Uganda. Economic Geology, 79, 716-724.

Spigel, R. H., Imberger, J., Rayner, K. N., 1986: Modeling the diurnal mixed layer. Limnol. Oceanogr., 31, 533-556.

Stager, J. C., Cumming, B., Meecher, L., 1997: A highresolution 11,400-year diatom record from Lake Victoria, East Africa. Quaternary Research, 47, 81-89.

Stewart, R. W., 1974: The air-sea momentum exchange. Bound.-Layer Meteor., 6, 151-167.

Straskraba, M., 1980: The effects of physical variables on freshwater production: analyses based on models. In: LeCren, E. D., McConnell, R. H. (eds.) The Functioning of Freshwater Ecosystems. Cambridge: Cambridge Univ. Press, pp. 13-84.

Strub, P. T., Powell, T. M., 1987: The exchange coefficients for latent and sensible heat flux over lakes: dependence upon atmospheric stability. Bound.-Layer Meteor., 40, 349-361.

Talling, J. F., 1963: The origin of stratification in an African rift lake. Limnol. Oceanogr., 8, 68-78.

Talling, J. F., 1965: The photosynthetic activity of phytoplankton in East African lakes. Int. Revue Ges. Hydrobiol., 50, 1-32.

Talling, J. F., 1966: The annual cycle of stratification and phytoplankton growth in Lake Victoria, East Africa. Int. Revue ges. Hydrobiol., 51, 545-621.

Yin, X., Nicholson, S. E., 1998: The water balance of Lake Victoria. Hydrological Sciences Journal, (in press).

Author's address: John T. Lehman, Department of Biology and Center for Great Lakes and Aquatic Sciences, Natural Science Building, University of Michigan, Ann Arbor, Michigan 48109, U.S.A. 